\title{
46, XY Female Karyotype Containing SRY
}

Taisuke Okada, Miwa Shinohara, Wakako Yokoyama, Makiko Koga, Haruko Maeda, Takashi Tomoda, Kumiko Araki, Takanobu Kurashige, Yutaka Nakahori and Yasuo Nakagome

Department of Pediatrics, Kochi Medical School (TO, MS, WY, MK, HM, TT, KA, TK), Kochi, Department of Human Genetics, School of International Health, University of Tokyo (YNakah, YNakag), Tokyo, Japan

Abstract We report the case of a girl with a 46, XY karyotype containing the sex determining region Y gene (SRY). She was 14 years old, with the height of $131.2 \mathrm{~cm}(-4.5 \mathrm{SD})$. She had a low hair line, shield-shaped chest and multiple pigmented naevi on her face. The external genitalia were normal female. No inguinal or labial masses were found. Chromosomal analysis from blood lymphocytes and skin fibroblasts revealed a 46, XY karyotype. The basal levels of serum luteinizing hormone ( $\mathrm{LH})$ and follicle stimulating hormone (FSH) and their responses to LH-releasing hormone (RH) stimulation were elevated; the insulin-like growth factor-I (IGF-I), thyroid function and growth hormone $(\mathrm{GH})$ secretory responses to insulin and glucagon were normal. SRY was identified on the short arm of the Y chromosome using Y-specific deoxyribonucleic acid (DNA) probes. There were no mutations in the SRY by direct sequencing analysis. Pelvic ultrasound and magnetic resonance imaging (MRI) did not reveal internal genitalia. Gonadectomy may be necessary because she has a substantial risk of developing malignant germ cell neoplasia. Two questions arise: 1) why was male sexual differentiation inhibited although she had a normal SRY, and 2) why did she have the appearance of Turner syndrome?

Key words: sexdetermining region $\mathrm{Y}$ gene, 46, XY female, Turner stigmata, polymerase chain reaction, gonadblastoma

\section{Introduction}

The mammalian Y chromosome plays a crucial part in sex determination: an embryo that inherits a $\mathrm{Y}$ chromosome develops as a male whereas an embryo lacking a $\mathrm{Y}$ chromosome develops as a female (1). The sex deter-

Correspondence: Dr. Taisuke Okada, Department of Pediatrics, Kochi Medical School, Kohasu, Oko-cho, Nankoku-shi, Kochi 783 Japan mining genes on the $\mathrm{Y}$ chromosome induce testicular development, and subsequent male sexual differentiation is a consequence of the hormonal products of the testis (2). The $\mathrm{Y}$ encoded testis determining gene has been named TDF in humans. In 1990, Sinclair predicted that the TDF gene must lie in the sex specific sequences within $35 \mathrm{~kb}$ of the pseudoautosomal boundary (3). The putative gene was called SRY. The 


\section{Okada et al.}

hypothesis that SRY is the gene for TDF has been supported by the finding of SRY in a 46 , $\mathrm{XY}$ male (4), and de novo mutations in SRY in two 46 , XY females (5-7). In addition, male development has been reported in chromosomally female mice transgenic for SRY (8). Recently, however, XX males who do not have SRY (9) and XY females who have SRY (10) have been described, suggesting that other parts of the testis-determining cascade remain to be described.

We report the case of a phenotypically normal female with 46, XY karyotype containing SRY.

\section{Case report}

The patient was born at 40-weeks' gestation with a height of $44 \mathrm{~cm}$, weighing $2,320 \mathrm{~g}$ and was treated by phototherapy for hyperbilirubinemia. She showed normal development apart from short stature. At the age of 9 years, she was admitted to Kochi Medical School Hospital because of short stature. Her height was $114.2 \mathrm{~cm}$ (-3.1 SD), and weight 20.8 $\mathrm{kg}(-1.6 \mathrm{SD})$ (Fig. 1). She had a low hair line, shield-shaped chest and multiple pigmented naevi on her face. Her external genitalia was normal female and no inguinal or labial masses were found. Chromosomal analysis from blood lymphocytes and skin fibroblasts showed a 46 , XY karyotype. The basal levels of serum gonadotropins and their responses to LH-RH stimulation were elevated. IGF-I, thyrotropin (TSH), thyroxine, triiodothyronine and adrenal function were normal (Table 1). Basal levels of serum testosterone and $5 \alpha$-dihydrotestosterone were $38 \mathrm{ng} / \mathrm{dL}$ and $<0.02 \mathrm{ng} / \mathrm{mL}$, respectively, and their responses to stimulation with human chorionic gonadotropine (hCG) were low (Table 2). Urinary levels of estrogen and urinary adrenal androgen were not elevated (Table 3). Serum GH responses after stimulation tests

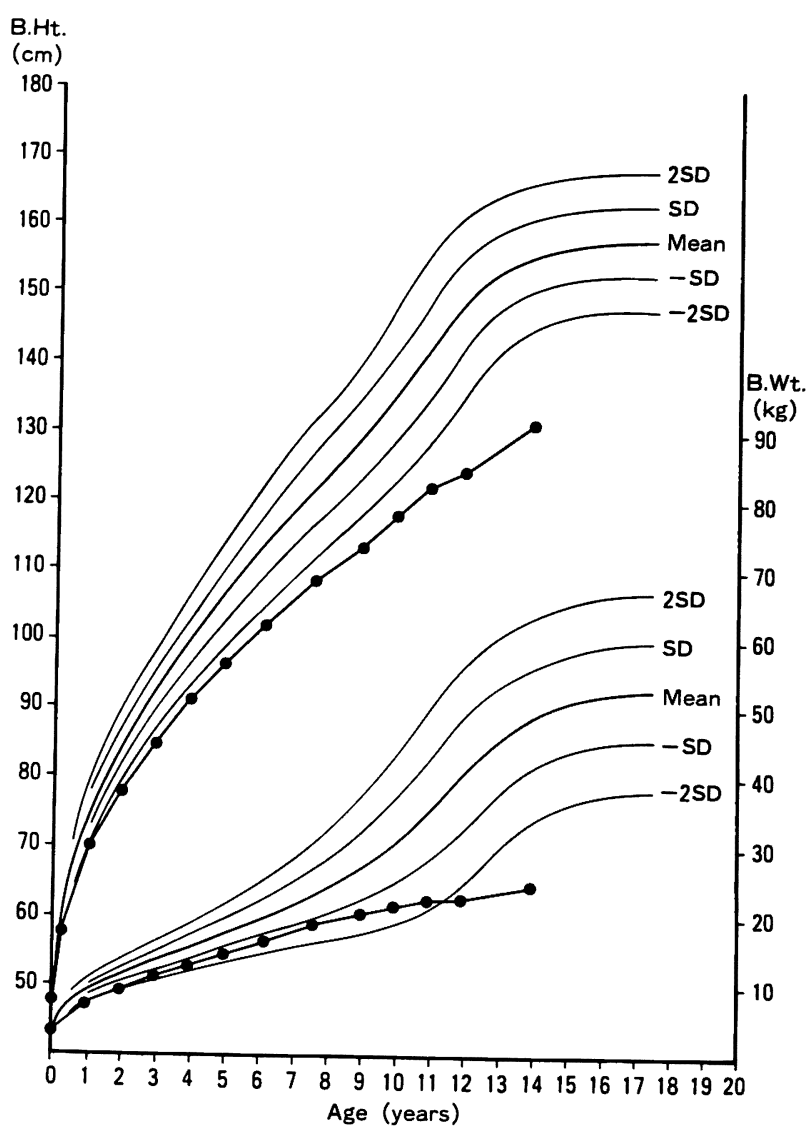

Fig. 1 Growth curve.

Table 1 Insulin, LH-RH, TRH test in July 1990.

\begin{tabular}{|l|ccrrrrc|}
\hline & 0 & 15 & 30 & 60 & 90 & 120 & $(\mathrm{~min})$ \\
\hline glucose & 86 & 37 & 42 & 55 & & & $(\mathrm{mg} / \mathrm{d} \ell)$ \\
ACTH & 50 & 58 & 230 & 110 & 110 & 140 & $(\mathrm{pg} / \mathrm{ml})$ \\
cortisol & 17.9 & & 29.2 & 31.7 & 33.3 & $34.8(\mu \mathrm{g} / \mathrm{d} \ell)$ \\
LH & 15.5 & 102.3 & 107.9 & 114.0 & 97.9 & $96.9(\mathrm{mIU} / \mathrm{m} \ell)$ \\
FSH & 180.5 & 198.1 & 219.2 & 242.2 & 252.1 & $256.7(\mathrm{mIU} / \mathrm{ml})$ \\
prolactin & 26.4 & 184.8 & 246.9 & 162.2 & 91.8 & $66.4(\mathrm{ng} / \mathrm{ml})$ \\
TSH & 1.4 & 8.0 & 7.8 & 5.4 & 3.5 & $2.7(\mu I U / \mathrm{ml})$ \\
T3 & 108 & & & & & & $(\mathrm{ng} / \mathrm{d} \ell)$ \\
T4 & 9.7 & & & & & & $(\mu \mathrm{g} / \mathrm{d} \ell)$ \\
IGF- I & 0.96 & & & & & & $(\mathrm{U} / \mathrm{ml})$ \\
testosterone & 30 & & & & & & $(\mathrm{ng} / \mathrm{d} \ell)$ \\
\hline
\end{tabular}




\section{A Case of 46, XY Female Contained SRY}

Table 2 HCG stimulation test (2,000 IU 3 days i.m.) in August 1990.

\begin{tabular}{|l|rrrr|}
\hline & \multicolumn{1}{|c}{0} & day 2 & day 4 & \\
\hline estradiol & $<10$ & $<10$ & 36 & $(\mathrm{pg} / \mathrm{ml})$ \\
& & & & \\
testosterone & 38 & 39 & 42 & $(\mathrm{ng} / \mathrm{d} \ell)$ \\
$5 a$-dihydrotestosterone & $<0.02$ & $<0.02$ & $<0.02$ & $(\mathrm{ng} / \mathrm{ml})$ \\
DHEA & $<0.5$ & $<0.5$ & $<0.5$ & $(\mathrm{ng} / \mathrm{ml})$ \\
DHEA-s & 430 & 440 & 410 & $(\mathrm{ng} / \mathrm{ml})$ \\
androstenedione & $<0.10$ & 0.16 & 0.19 & $(\mathrm{ng} / \mathrm{ml})$ \\
\hline
\end{tabular}

Table 3 Urinary hormones July 1990.

\begin{tabular}{|l|rrrr|}
\hline & day 1 & day 2 & day 3 & \\
\hline $17-$ KGS & 3.7 & 3.6 & 5.1 & $(\mathrm{mg} /$ day $)$ \\
$17-$ OHCS & 2.2 & 2.3 & 2.9 & $(\mathrm{mg} /$ day $)$ \\
$17-\mathrm{KS}$ & 0.7 & 0.6 & 1.0 & $(\mathrm{mg} /$ day $)$ \\
$E_{1}$ & 0.7 & 0.7 & 0.5 & $(\mu \mathrm{g} /$ day $)$ \\
$E_{2}$ & $<0.1$ & $<0.1$ & $<0.1$ & $(\mu \mathrm{g} /$ day $)$ \\
$E_{3}$ & $<0.3$ & $<0.3$ & $<0.3$ & $(\mu \mathrm{g} /$ day $)$ \\
\hline
\end{tabular}

Table 4 Serum GH responses after various stimulations in July 1990.

\begin{tabular}{|l|cccccccc|}
\hline & 0 & 15 & 30 & 60 & 90 & 120 & 180 & $(\mathrm{~min})$ \\
\hline insulin & 0.2 & 0.3 & 2.3 & 10.8 & 3.4 & 0.9 & & $(\mathrm{ng} / \mathrm{ml})$ \\
1-dopa & 1.6 & & 1.8 & 1.2 & 0.6 & 1.0 & & $(\mathrm{ng} / \mathrm{ml})$ \\
glucagon & 1.8 & & & & 3.9 & 11.1 & 5.7 & $(\mathrm{ng} / \mathrm{ml})$ \\
glucagon - propranolol & 0.2 & & & & 2.1 & 39.1 & 17.7 & $(\mathrm{ng} / \mathrm{ml})$ \\
\hline
\end{tabular}

were normal (Table 4). Pelvic ultrasound did not reveal gonads or uterus. SRY was identified on the short arm of her $\mathrm{Y}$ chromosome by the use of Y-specific DNA probes. There were no mutations in SRY by direct sequencing analysis (Fig. 2).

At the age of 14 years, her height was $131.2 \mathrm{~cm}(-4.5 \mathrm{SD})$ and weight was $23 \mathrm{~kg}(-3.5$ SD). Breast development was Tanner stage I

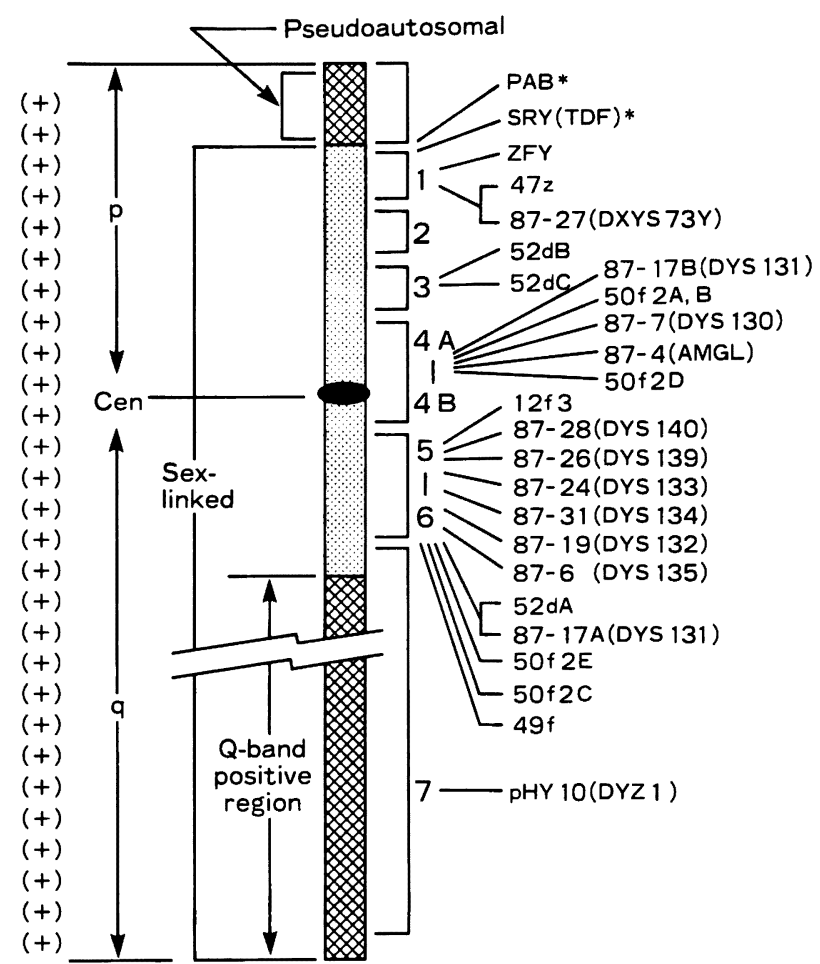

Fig. 2 On the short arm of the Y chromosome, SRY was identified by the use of Y-specific DNA probe.

and pubic hair was also Tanner stage I. Her vagina was about $7 \mathrm{~cm}$ in length with a blind end. Her IQ by Wechsler intelligence scale for children (WISC)-R was 98. Pelvic MRI did not reveal gonads and uterus.

\section{Discussion}

At first, she was suspected to have Turner syndrome because of short stature, low hair line, shield-shaped chest, multiple pigmented naevi, and normal female external genitalia. However, repeated cytogenetic studies of blood lymphocytes and skin fibroblasts, revealed a 46, XY karyotype. Ribosomal protein S4X (RPS $4 \mathrm{X}$ ) and RPS $4 \mathrm{Y}$, which may be one of the determinants preventing Turner phenotype 


\section{Okada et al.}

(11), were normal. Therefore, the XY Turner female was excluded. As basal levels of serum testosterone and $5 \alpha$-dihydrotestosterone and their responses to stimulation with hCG were low, the androgen insensitivity syndrome was also excluded.

She was diagnosed as a $46, \mathrm{XY}$ female and examined for SRY, which directs the undifferentiated gonad to develop into a testis. There were no mutations in SRY by direct sequencing analysis. Why didn't male differentiation take place in this case? It is possible that SRY is a component of the pathway of genes required for testicular differentiation and acts as a switch in human sex determination and that a mutation may be found in a regulatory gene of the SRY or further downstream in the gene regulating testicular formation. The complete process which regulates male differentiation has not yet been elucidated. Furthermore, this theory does not explain why she was short in stature although XY females are usually taller than average females. Both sex chromosomes carry determinants important for stature. Ylinked stature determinants appear to have a greater effect on skeletal growth than X-linked determinants. She might have had a mutation in the $\mathrm{Y}$ determinants for stature which are proximal to those which prevent Turner syndrome and have not yet been found.

Another problem is that gonadectomy may be necessary because she has a substantial risk of developing malignant germ cell neoplasia, such as gonadoblastoma or dysgerminoma. The etiology of gonadal tumors in 46, XY females has not been established but the increased prevalence of gonadal neoplasia has been suggested to result from poorly differentiated 46 , $\mathrm{XY}$ gonadal tissues in an abnormal environ- ment $(12,13)$. That is, as the $\mathrm{XY}$ germ cells fail to mature within an ovarian environment, the ovaries do not develop normally and by puberty are represented by thin gonadal streaks identical to the streak gonads usally found in Turner syndrome. Sometimes germ cell nests are present which may develop into malignant tumors (14). To avoid the risk of developing these tumors, gonadectomy is recommended in such patients before puberty. However, as keloid formation was induced by skin biopsy in this patient, we hesitated to perform an abdominal operation. However, laparoscopy is an alternative and probably safer method.

\section{References}

1. Goodfellow PN, Darling SM. Genetics of sex determination in man and mouse. Development 1988; 102: 251-8

2. Jost A, Vigier B, Prepin J, Perchellet JP. Studies on sex differentiation in mammals. Recent Prog Horm Res 1973; 29: 1-41.

3. Sinclair AH, Berta P, Palmer MS, Hawkins JR, Griffiths BL, Smith MJ, et al. A gene from the human sex-determining region encodes a protein with homology to a conserved DNA-binding motif. Nature 1990; 346: 240-4.

4. Palmer MS, Sinclair AH, Berta P, Ellis NA, Goodfellow PN, Abbas NE, et al. Genetic evidence that ZFY is not the testis-determining factor. Nature 1989; 342: 937-9.

5. Berta P, Hawkins RJ, Sinclair AH, Taylor A, Griffiths BL, Goodfellow PN, et al. Genetic evidence equating SRY and the testis-determining factor. Nature 1990; 348: 448-50.

6. Jager RJ, Anvert M, Hall K, Scherer G. A 


\section{A Case of 46, XY Female Contained SRY}

human $\mathrm{XY}$ female with a frame shift mutation in the candidate testis-determining gene SRY. Nature 1990; 348: 452-4.

7. Hawkins JR, Taylor A, Levilliers J, Van der Auwera B, Goodfellow PN. Mutation analysis of SRY: nonsense and missense in $\mathrm{XY}$ sex reversal. Hum Genet 1992; 88: 471-4.

8. Koopman P, Gubbay J, Vivian N, Goodfellow P, Lovell-Badge R. Male development of chromosomally female mice transgenic for Sry. Nature 1991; 351: 11721.

9. North M, Affara N, Ferguson-Smith MA. Analysis of SRY, the present candidate testis determining factor (TDF), in sex reversed patients and evidence for novel regulation of the zinc fingergene $\mathrm{ZFY}$, the previous candidate TDF. J Med Genet 1991; 28: 550-61

10. Muller J, Schwartz M, Skakkebek NE. Analysis of the sex-determining region of the $\mathrm{Y}$ chromosome (SRY) in sex reversed patients: point-mutation in SRY causing sex-reversion in a $46, \mathrm{XY}$ female. J Clin Endocrinol Metab 1992; 75: 331-3.

11. Fisher EMC, Beer-Romero P, Brown LG, Ridley A, McNeil JA, Lawrence JB, et al. Homologous ribosomal protein genes on the human $\mathrm{X}$ and $\mathrm{Y}$ chromosomes: Escape from $\mathrm{X}$ inactivation and possible implications for Turner syndrome. Cell 1990; 61: 1205-18.

12. Sandberg AA. Neoplasia in Turner syndrome. Basic and clinical approach to Turner syndrome (Proceeding) the 3rd 1993; 3947.

13. Verp MS, Simpson JL. Abnormal sexual differentiation and neoplasia. Cancer genet Cytogenet 1987; 25: 191-218.

14. Ferguson-Smith MA. Genotype-phenotype correlations in individuals with disorders of sex determination and development including Turner syndrome. Dev Biol 1991; 2: 265-76. 